\title{
Impact of Cornell Note-Taking Method Instruction on Grammar Learning of Iranian EFL Learners
}

\author{
Mohammad Davoudi, \\ Hakim Sabzevari University, Sabzevar, Iran \\ E-mail: davoudi2100@yahoo.com \\ Neda Moattarian, \\ Hakim Sabzevari University, Sabzevar, Iran \\ E-mail: neda_moattarian@yahoo.com \\ Gholamreza Zareian \\ Hakim Sabzevari University, Sabzevar, Iran \\ E-mail: g.zareian@hsu.ac.ir
}

Received: Feb. 25, 2015 Accepted: March 24, 2015 Published: May 28, 2015

doi:10.5296/jse.v5i2.6874 URL: http://dx.doi.org/10.5296/jse.v5i2.6874

\begin{abstract}
Given the potential benefits of classroom note taking as an essential learning strategy, the aim of the present study was to investigate how effective Cornell note-taking instruction and use could be in language grammar learning process. The variable of gender was also taken into consideration. For these reasons, 70 intermediate EFL students, 44 males and 26 females, formed two homogenous groups and underwent an experiment in which, after both groups took a pre-test, the experimental group received special training on how to take Cornell notes. Then, the two groups were exposed to grammar instruction. When the treatment was over, a test of grammar was administered to both groups. A careful examination of the data, using a series of T-tests, clearly depicted that the experimental group had outperformed the control one. With respect to the variable of gender, no significant difference was observed between the two groups. The conclusions were further discussed and used to develop some practical applications of the study.
\end{abstract}

Keywords: Cornell note taking, Grammar learning, Instruction 


\section{Introduction}

Since the demand for language learning has increased, many theories and researchers have tried to tackle the problems teachers and students face in the whole language learning process by providing teachers and learners with, presumably, a better way of learning foreign languages (Lewis \& Hill, 1995). Hence, a great body of research has been carried out on the influence of strategies used by EFL learners that can facilitate the internalization, storage, retrieval or use of the new language. Successful learners often use metacognitive strategies such as organizing, evaluating, and planning their learning (Oxford, 1990). Use of these behaviors accompanied with cognitive strategies such as analyzing, reasoning, transferring information, taking notes and summarizing characterizes a truly effective learning process (Brown, Bransford, Ferrara, \& Campione, 1983).Note taking is one of the strategies considered in many studies to be effective in improving students' learning (Baker \& Lombardi, 1985; Boyle \& Weishaar, 2001; Di Vesta \& Gray, 1973; Fisher \& Harris, 1973; Hartley, 1983; Kiewra, 1985a). However, it is not the case that all readers know how to take effective note. Whereas some students are successful in developing effective learning strategies on their own, others need to be taught them clearly (Çetingöz, 2010).

Theoretically, there are three hypotheses supporting the seriousness of the issue (Kiewra, 1985b; Ward \& Tatsukawa, 2003; White, 1996;):

1. Encoding Hypothesis: Note-taking increases attention.Therefore, it is advantageous in itself, even without later review. Deeper meaning, better understanding and better results on an assessment (Baker \& Lombardi, 1985; Kiewra, 1985a) provide the grounds for encoding hypothesis to focus on process functions of note-taking.

2. External Storage Hypothesis: This hypothesis holds the view that notes are means of recording information for later use. Thus, the review of notes leads to a better performance. Having had the notes reviewed, students achieve better results in tests (Kiewra, 1985b); Kiewra, Benton, Kim, Risch, \& Christensen, 1995) due to the product effect of notetaking.

3. Generative Hypothesis: It was introduced by Peper and Mayer (1978). David H. Jonassen (1984), in his book The Technology of Text, volume two, fully explains how close generative and encoding hypotheses are:

The generative hypothesis of note- taking is an elaboration of encoding hypothesis. It predicts that the benefits of note-taking occur on the encoding end of the memory process. It more clearly specifies the nature of the cognitive processing that should occur during encoding. If note- taking is generative, the information in a text needs to be transformed and elaborated on in terms of distinctive memory traces (p: 26).

\section{Review of Literature}

Historically, as referred to by Castello and Monereo (2005), there are different eras of note-taking research. In the sixties and seventies, researchers mostly focused on the effects of note taking and note writing on attention, memory, comprehension, and so on. They tried 
to investigate how note taking and note writing can affect cognitive variables, such as the ones aforementioned. In the eighties and nineties, the focus shifted to establishing a relationship between quality of notes and significance of learning. More specifically, these studies analyzed whether the use of different note-taking procedures improved the learning of some information. More recently, prompting certain note-taking forms and what really happens in the classroom when the teacher does so has drawn attention and taken over other interests in the field.

One of the most significant modelsof note taking is Cornell method.The Cornell method provides a systematic format for condensing and organizing notes without laborious recopying. The process of note taking in this model works in this way: After writing the notes in the main space, the left-hand space is used to label each idea and detail with a key word or "cue." The paper is ruled with a margin on the left leaving a bigger area on the right in which to make notes. During class, the notes are written in the bigger area. When the instructor moves to a new point, students skip a few lines. After class, they complete phrases and sentences as much as possible. For every significant bit of information, the students are required to write a cue in the left margin. To review, notes are covered with a card, leaving the cues exposed. Reading the cues, they try to say as much as they can of the material underneath the card. Then the card is removed in order to check the recalled information. Cornell note-taking method is organized and systematic for recording and reviewing notes. The easy format for pulling out major concept and ideas makes it a simple and efficient method that saves time and effort. It can also be used in any lecture situation.

Regarding the potential relationship between lectures note taking and academic achievement, Spires and Stone (1989) point out that "students will increasingly have to depend on their ability to take notes in order to be successful in the classroom" (p. 36) Armbruster (2000) calls note taking the students' "pet calf" compared to lecturing which is teachers' "sacred cow" because college students usually spend about $\% 80$ of class time listening to lectures.

In the U.S, both college students and professors hold the same view about note taking. They think that taking notes on lecture information contributes to the process of learning and retaining the information and is a time-honored tradition in academic context (Dunkel\& Davy, 1989). These researchers came to the conclusion that the student view of note taking and the considerable variation in how lectures are conceptualized by them give insights into this strategy and are necessary adjuncts to other kinds of research in this area (Dunkel\& Davy, 1989). In the same vein, Badger, White and Sutherland, (2001) suggests that the aim of taking notes is to recall the content of the lecture as much as possible. The process aids concentration in the lectures and the product provides material for review.

Considering Cornell note taking, in particular, there have been a number of studies as well. In Williams' (2004) research, students worked on Cornell note-taking strategy and the data was collected through interviewing. The results of the research showed that students believed in the importance of note taking and they thought Cornell method was a beneficial tool to organize the information. Faber, Morris and Lieberman (2000) found out that Cornell note-taking method is an effective note-taking method and instruction of this strategy has a 
significant effect on students' comprehension when taking some teacher-made objective tests based on texts. In another study, $\mathrm{Wu}$ and Tsai-Fu (2010) tried to investigate the effects of note-taking instruction, using the Cornell note-taking method and also note-taking language (English vs. Chinese) on Taiwanese college students' English listening comprehension for two types of texts, specifically, short conversations and long lectures. They proved that instruction had a significant impact on the listening comprehension of both types of texts, regardless of the language used for taking notes. Participants who took notes in English outperformed their peers, and those who received the combined effects of both instruction and taking note in English scored substantially higher than any other conditions. Stahl, King and Henk (1991) stated that the Cornell Method, the Unified Note-taking System and the Split Page Method are all effective, "time-honored tactics" (p. 615).

However, in another study, Quintus, Borr, Duffield, Napoleon, \& Welch (2012) showed that there was not a significant difference in students' performance between those who had taken Cornell notes and those who had used a note-taking method by their own choice that gave them the freedom not to take notes at all, hence affecting the results of the study unfavorably.

Last but not least, Cornell note-taking system has been used in many environments with a variety of subject matters. Broe (2013) investigated the effects of Cornell Method on mathematic students' achievement, concluding that it is a beneficial method. Zorn (2007) used the method to show its effect on American History and Language Arts, showing that student' test scores improved substantially, by an average of $24.5 \%$ in History and $20.4 \%$ in Language Arts.

Some gender-based studies also show a link between process and product function of note taking and students' sex. In a study conducted by Kiewra (1984), female students noted more critical points, test-related points, and words than did male students. Also, females significantly outscored males on delayed exams over lecture material. However, it must be noted that the sample based on which he drew conclusions consisted of 22 female and only 7 males which could have a significant effect on the results. Later, Cohn, Cohn and Bradley (1995) showed that females recorded more words than males, including more detailed information about the subject matter. Eggert and Williams (2002) showed that females notes were more complete, extended and accurate compared to males'. Carrier, Williams, and Dalgaard (1988) examined the relationship between note-taking preferences and gender in a macroeconomics course. First, the Note Taking Perceptions Survey was used to determine students' note-taking preferences (Carrier \& Newell, 1984). The results indicated that females valued note-taking more than males, had greater confidence in their note-taking skills, and viewed themselves as more active note takers (Carrier et al., 1988).

Note taking is widely considered as a valuable tool that can help increase the retention of information (Meyer, 2002). Over the last 30 years, despite an abundance of research studies on the effects of note-taking training on achievement, many of them have been inconclusive regarding the benefits of note-taking training. However, some of these studies have had serious methodological weaknesses and have not consistently involved meaningful training sessions that incorporate practice and evaluation of the note-taking skills. For example, a 
study by Bretzing, Kulhavy and Caterino (1987) involved 15 minute training sessions before the testing and provided only general note-taking tips. Peck and Hannafin (1983) conducted a similar research to gain insight into this issue.

In all of these studies, one or more experimental groups received special note-taking training, while one or more groups received no formal training. The results of Peck and Hannafin's (1983) study showed that the uninstructed note takers actually performed better on all three tests. Peck and Hannafin (1983) suggested that the results were a product of an "interference effect" in which the process of note taking itself interfered with the retention of information.

As it was stated earlier, the functional complexity of note taking is such that at least three skills need to be taught: comprehension through note taking, producing notes, and the conscious management of the activity as a whole (Stahl, et al. 1991). Very little work has been done on learning conditions and measuring the evolution of the knowledge and skills used in note taking, whether for school or university students. At the school level, apart from some exercises focusing on specialist psycholinguistic, production of summaries is also a criterion for comprehension (Vigner, 1991). Producing a summary involves sorting, selecting and combining the information contained in a text with a standardized language format (respecting spelling, syntax, linearity of the text). A student who masters the art of summarizing will be able to take notes in the form of "data sheets," but summarizing is a difficult comprehension exercise to master, even for adults. Friend (2001) clearly showed that learning to extract information from a text, and then to sort it and classify it into a hierarchy is beneficial for first-year university students taking remedial courses to improve their ability to create texts. The effectiveness of this type of training is further enhanced by the fact that it also involves combining and generalizing the important pieces of information that have been extracted from a text.

To date, note taking has not been widely studied because of its functional complexity and the need to develop methods in order to carry out such studies (Piolat, Olive \& Kellogg, 2004). This functional complexity also accounts for the lack of specific note-taking training in schools and universities. Teaching is limited to the production of summary texts involving the sorting, ranking, and reformulation of what the student has read or heard. Having been shown how to take notes, students are able to produce notes of higher quality (Gray \&Madson, 2007). However, no instruction has focused on training EFL students to use a special kind of note-taking strategy called Cornell Note Taking in a grammar class. This is where the present study comes into the picture trying to fill in thegaps to the extent possible.

This project seeks to investigate the effectiveness of Cornell note-taking instruction on grammar learning and also establish a relationship between its effects and students' gender. It strives tofind answers to the following questions:

1. Is there a relationship between Cornell note-taking method instruction and EFL learners' grammar learning?

2. Is there a relationship between EFL learners' gender and their grammar learning using Cornell note-taking method? 
In an attempt to investigate the above-mentioned questions, the following null hypotheses are put forward in this study:

1. There is not a relationship between Cornell note-taking method instruction and EFL learners' grammar learning.

2. There is no relationship between EFL learners' gender and their grammar learning using Cornell note-taking method.

\section{Method}

\subsection{Participants}

The present study involved a total of 70 students who were selected from among Iranian intermediate EFL learners from three language schools. Students' participation in the study was on a voluntary basis. Based on demographic datacollected from the questionnaire, all participants were between 22 and 32 years old and were mostly B.A and B.S holders with a job, mostly one that required a command of English language. They mostly claimed to spend between 7 to 9 hours a week studying English, including the time they spent in the English classroom. Out of 70 participants, 44 were male and 26 were female. The participants of the study were assigned into two groups of experimental and control group. Care was taken to take into account the age and the gender of the participants so that they formed homogenous groups as much as possible. The control and experimental groups were chosen through random sampling procedure. In the experimental group, there were 23 males and 12 females, totaling 35 participants, and the control group comprised 21 male and 14 females, totaling 35 participants. All the participants were familiarized with of the objectives of the study as a whole and its aims and hypotheses and the fact that they were going to be involved in all phases (including grammar lessons, note-taking instruction and tests).

\subsection{Materials}

The materials included a grammar pre-test to check the participants' current knowledge of grammar, video podcasts and power-point slides on Cornell note taking and a grammar post-test to determine students' level of achievement. The pre-test and the post-test used in this study were 2 parallel tests offered by the test book of American English File 3 since it was the main book that had been taught in the aforementioned institutes. Each test contained 100 grammatical questions based on the material the student book introduced. The video podcasts were downloaded from internet mostly as an aid to model taking notes and make it more tangible for the students. Throughout the course, 5 videos were played: one on page division, another on abbreviated language used in notes, two other on the use of the system in a real class, and the last on students attitudes toward it. The last one served as a way to raise motivation toward taking Cornell notes.During the training sessions, 3 sets of power-point slides were used. The first one was a general introduction to Cornell notes and note taking. The second was on how to differentiate the main idea from details, which is an important issue in Cornell note taking. The last set served as a summary of the whole sessions. It recapitulated all the important issues the students had been introduced during the note-taking training course. 


\subsection{Procedure}

The research involved four phases: the pre-training phase, the training phase, the grammar lessons and the post-training phase (see Figure 1).

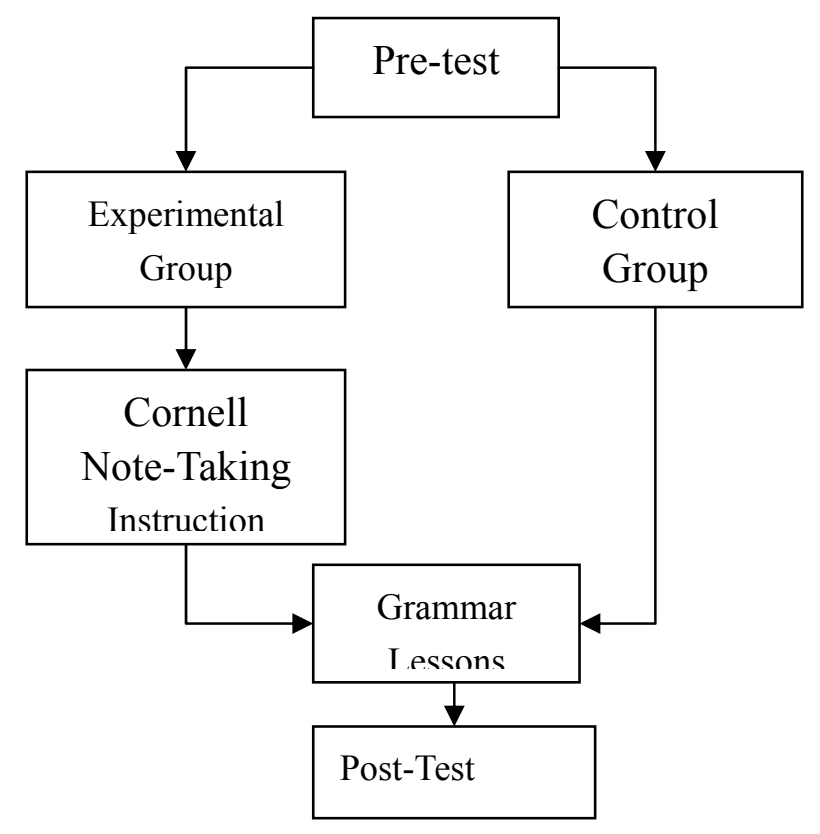

Figure 1. Schematic Representation of the Flow of Participant in Different Phases

First, a pre-test was administered to both groups to determine the students' baseline knowledge and their preparedness for the experiment. The scores gained from this phase were used to serve as a yardstick for possible changes. The second phase generally involved training the experimental group to take notes using Cornell method and encouraging the control group to simply take notes during grammar lessons. The students in the experimental group were familiarized with the method using power point slides, video clips and the whiteboard for teacher's demonstration, emphasizing the benefits it results and the points they should consider doing it. This phase included 5 sessions of training with each session taking an hour to complete. Having been trained on how to take notes using Cornell method, the experimental group attended 5 grammar sessions each lasting for 90 minutes and was asked to take notes using the previously taught method. The control group also attended the same classes using their own note-taking method. At the end of each lesson, students' notes in the experimental group were checked in terms of accuracy of the method. Also, both groups' notes were carefully examined to ensure that no mistakes had been written down regarding the grammatical points. However, the note-taking method of the control group was kept intact. All participants took an achievement test parallel to the pre-test on the taught grammatical content and the results were used to determine the high-achievers and low-achievers' progress and also for the comparison of the two groups. To examine the hypotheses, data, which in this case was students' score on the pre-test and post-test in both groups, was computed and analyzed using IBM SPSS Statistics 22. The normality of the data was checked using Kolmogorov-Smirnov and Shapiro-Wilk tests for both experimental and 
control groups, prior to any other analysis. Since the two groups were independent from each other, a series of Independent-Samples T-test were computed, first to ensure that the groups were homogenous before the treatment, and once again to measure the statistical differences in means after the treatment, that is to say, on the post-test. Since the homogeneity of the groups was checked in all tests before the treatment, it could be concluded that any possible changes observed were due to the independent variables in each research question. The statistical significance of the differences in mean was determined after an appropriate $t$ was selected based on Levene's test. Based on the tables, figures were drawn to show the differences graphically.

\section{Findings of the Study}

First, the normal distribution of the pre-tests and post-tests for both experimental and control groups was examined.To see whether teaching Cornell note-taking method, as an independent variable, affects EFL learners' grammar learning, as a dependent variable, after assuring the normality of the tests, homogeneity of the control and experimental groups in pre-test was examined since the two groups should be homogeneous in the pre-test to ensure that both are at the same level of grammatical ability before the treatment.

Descriptive statistics for both groups' performance on pre-test is given in Table 1.

Table 1. Descriptive statistics of pre-test

\begin{tabular}{llllll}
\hline Scores & Group & N & Mean & SD & SE Mean \\
\hline Score 1 & Exp. & 35 & 81.9143 & 5.46847 & .92434 \\
& Con. & 35 & 83.1286 & 3.98590 & .67374 \\
\hline
\end{tabular}

Note. Exp. $=$ experimental group. Cont. $=$ Control group. $1=$ score on pre-test. $\mathrm{SD}=$ standard deviation. $\mathrm{SE}=$ standard error mean

The obtained mean of the control group was 83.12 and that of the experimental group was 81.91. To see whether this difference is statistically significant, independent-samples t-test was run. Results can be seen in Table 2.

Table 2. Independent Samples Test of means before treatment

\begin{tabular}{|c|c|c|c|c|c|c|c|}
\hline \multicolumn{2}{|c|}{ Variance of Score } & \multicolumn{2}{|c|}{ Levene's Test } & \multicolumn{4}{|l|}{ T-test } \\
\hline & & $F$ & Sig. & $\mathrm{T}$ & Df & $\begin{array}{l}\text { Sig. } \\
\text { (2-tailed) }\end{array}$ & MD \\
\hline \multirow[t]{2}{*}{ Score 1} & $\begin{array}{ll}\text { Equal } & \text { var. } \\
\text { assumed } & \end{array}$ & 1.812 & .183 & -1.773 & 68 & .080 & -1.21429 \\
\hline & $\begin{array}{l}\text { Equal var. not } \\
\text { assumed }\end{array}$ & & & -1.773 & 62.17 & .081 & -1.21429 \\
\hline
\end{tabular}

Note. $1=$ score on pre-test. Sig. = significance. $\mathrm{MD}=$ mean differences. var. =variance.

Based on Levene's test, the appropriate $t$ was selected. As Table 2 shows, there is no significant difference between experimental and control groups $(t=-.1 .77, \mathrm{df}=68, \mathrm{p}>.05)$. 


\section{Macrothink}

This lack of significance implies that there was no significant difference between control and experimental groups before the treatment. In other words, the two groups were homogeneous. Therefore, if there is any difference between the two groups' performance in post-test, it would be merely due to the treatment.

Descriptive statistics for both groups in post-test is given in Table 3.The mean of the control group is 89.62 and that of the experimental group is 92.9 .

Table 3. Descriptive statistics of post-test

\begin{tabular}{llllll}
\hline Score & Group & N & Mean & SD & SE \\
\hline Score 2 & Exp. & 35 & 92.914 & 3.68918 & .62359 \\
& Cont. & 35 & 89.628 & 4.44632 & .75156 \\
\hline
\end{tabular}

Note. Exp. $=$ experimental group. Cont. $=$ Control group. $2=$ score on post-test. $\mathrm{SD}=$ standard deviation. $\mathrm{SE}=$ standard error mean

Once again, an independent-samples t-test was run to see whether this difference is statistically significant. Results can be seen in Table 4.

Table 4. Independent Samples Test of means after treatment

\begin{tabular}{llllllll}
\hline Variance of Score & \multicolumn{5}{l}{ Levene's Test } & \multicolumn{2}{l}{ T-test } \\
\cline { 2 - 7 } & & $\mathrm{F}$ & Sig. & $\mathrm{T}$ & Df. & $\begin{array}{l}\text { Sig. } \\
\text { (2-tailed) }\end{array}$ & $\mathrm{MD}$ \\
\hline $\begin{array}{l}\text { Score } \\
2\end{array}$ & $\begin{array}{l}\text { Equal var. } \\
\text { Assumed } \\
\begin{array}{l}\text { Equal var. not } \\
\text { assumed }\end{array}\end{array}$ & .741 & .392 & 3.365 & 68 & .001 & 3.28571 \\
\hline
\end{tabular}

Note. $2=$ score on post-test. Sig. $=$ significance. $\mathrm{MD}=$ mean differences. var. $=$ variance.

Based on Levene's test, the appropriate $\mathrm{t}$ was selected. As Table 4 shows, there is a significant difference between experimental and control group $(\mathrm{t}=3.36, \mathrm{df}=68, \mathrm{p}<.05)$. As the mean of the experimental group ( $M=92.91)$ is higher than that of the control group $(M=89.62)$, it can be concluded that the experimental group had a better performance in post-test of grammar compared to the control group. In other words, the treatment of the study which was in the form of Cornell note-taking method instruction has a positive effect on Iranian EFL learners' performance on a grammar test.

Then, the mean for male and female was computed for the post-test. The mean was 90.63 for the male students and 92.34 for females. 
Table 5. Males and Females' Means

\begin{tabular}{lllllll}
\hline \multicolumn{7}{l}{ Independent Samples Test } \\
\hline \multicolumn{7}{l}{ Levene's Test } \\
& & $\mathrm{F}$ & $\mathrm{Sig}$. & $\mathrm{t}$ & $\mathrm{df}$ & Sig. (2-tailed) \\
\hline Group & $\begin{array}{l}\text { Equal variances } \\
\text { assumed }\end{array}$ & .068 & .796 & -.488 & 68 & .627 \\
& $\begin{array}{l}\text { Equal variances } \\
\text { not assumed }\end{array}$ & & & -.488 & 52.334 & .628 \\
ScoreAfter & $\begin{array}{l}\text { Equal variances } \\
\text { Traning }\end{array}$ & 1.880 & .175 & -1.596 & 68 & .115 \\
& $\begin{array}{l}\text { Equal variances } \\
\text { not assumed }\end{array}$ & & -1.695 & 62.278 & .095 \\
\hline
\end{tabular}

Note: $\mathrm{N}=$ number. $\mathrm{Std}=$ Standard

Table 5 shows that there is no significant difference in means for male and female students.

\section{Discussion \& Conclusion}

The obtained result of the present study rejects the first null hypothesis and shows the existence of relationship between Cornell note-taking method instruction and EFL learners' grammar learning. It strongly confirms the conclusions drawn by Crawford (1925) and DiVestaand Gray (1973) on how justified the note-taking process is in itself. Improvement on the post-test of both experimental and control group clearly shows that note taking does improve test performance. It is even more significant if done in an organized way such as Cornell method.

Furthermore, review of the notes is integrally a part of Cornell system. Since Cornell notes, taken by students in the current experiment, were reviewed at the end of each grammar lesson to ensure their accuracy, it can be claimed that a subsequent review of notes results in higher achievement, as found by Kiewra (1985b).

Considering the importance of instruction, as Najar (1997) found, making students aware of note taking as being a learning strategy can have a positive effect on learning, which in this case was grammar learning. Teaching the abbreviated language to students also helps them jot down more information in a shorter time and reduce the cognitive overload and, therefore, enhance retention, which was also evident in studies by Graham, Berninger, Abbott, Abbott, and Whitaker (1997) and Jones and Christensen (1999). Moreover, as Cetingoz (2010) has proposed, note-taking instruction increases learning quality for it make the students more active in the strategy-learning process and usage.

Unlike what was shown by Kiewra (1984), in the current study, no statistically significant difference was found between male and female participants. That is to say, the third null hypothesis is retained and the results show that there is no relationship between EFL learners' gender and their grammar learning using Cornell note-taking method. The means show that 
the variable of gender does not make a significant difference in their performance on grammar learning using Cornell notes.

All in all, Cornell note-taking instruction has the potential to help students overcome their note-taking difficulties and achieve more grammatical knowledge. It also encourages critical thinking, enabling learners answer higher-order thinking skills items on a test, disregard of their gender.

However, one aspect that was not included in this study due to the limited time and resources was the attitudes of teachers and students toward the Cornell note-taking system, especially after the students were trained on how to do it. It is suggested that further investigations address qualitative aspect of the system and its effects on employment of the system since it can be one of the variables that affects the process, negatively or positively. It is also recommended that research focuses on the age of participants as another independent variable because thinking skills can differ greatly as a matter of aging. As for the language components and skills, the effects of Cornell notes can also be explored on other skills such as reading and some components namely vocabulary learning.

\section{References}

Armbruster, B. B. (2000). Taking notes from lectures. In R. F. Fippo and D. C. Caverly (Eds.), Handbook of college reading and study strategy research (pp, 175-199). N. J.: Mahwah, Erlbaum.

Badger, R., White, G.\& Sutherland, P. (2001). Note perfect: An investigation of how students view taking notes in lectures. System, 29(3), 405-417. http://dx.doi.org/10.1016/S0346-251X(01)00028-8

Baker, L., \& Lombardi, B. R. (1985). Students' lecture notes and their relation to test $\begin{array}{lllll}\text { performance. } & \text { Teaching } & \text { of } & \text { Psychology, } & \text { 12(1), }\end{array}$ http://dx.doi.org/10.1207/s15328023top1201_9

Boyle, J. R. \& Weishaar, M. (2001). The effect of strategic note-taking on the recall and reading comprehension of lecture information for high school students with learning disabilities. Learning Disabilities Research \& Practice, 16(3), 133-141. http://dx.doi.org/10.1111/0938-8982.00014

Bretzing, B., Kulhavy, R.W.\& Caterino, L.C. (1987). Note-taking by junior high school students. Journal of Educational Research, 80(6), 359-362. http://dx.doi.org/10.1080/00220671.1987.10885783

Broe, D. (2013). The effects of teaching Cornell notes on student achievement. (Unpublished master's thesis), Minot State University. Minot, North Dakota.

Brown, A., Branford, J., Ferrara, R., \& Campione, J. (1983). Learning, remembering, and understanding. In P. H. Mussen (Series Ed.) \& J. Flavell \& E. Markman (Eds.), Handbook of child psychology: Vol. 3. Cognitive development (4th ed., pp.77-166). New York: Wiley. 
Carrier, C. A., \& Newell, K. (1984). What dental hygiene students think about note-taking: Report of a survey. Canadian Dental Hygienist, 18, 13-17. http://dx.doi.org/10.1007/BF00992232

Carrier, C. A., Williams, M. D., \& Dalgaard, B. R. (1988). College students' perceptions of note-taking and their relationship to selected learner characteristics and course achievement. Research in Higher Education, 28, 223-239.

Castello, M., \& Monereo, C. (2005). Students' note-taking as a knowledge-construction tool. Educational Studies in Language and Literature, 5, 265-285. http://dx.doi.org/10.1007/s10674-005-8557-4

Çetingöz, D. (2010). University students' learning processes of note-taking strategies. Procedia Social and Behavioral Sciences, 4098-4108. http://dx.doi.org/10.1016/j.sbspro.2010.03.647

Cohn, E., Cohn, S., \& Bradley, J. (1995). Notetaking, working memory, and learning in principles of economics. Journal of Economic Education, 26(4), 291-307. http://dx.doi.org/10.1080/00220485.1995.10844880

Crawford, C. C. (1925). Some experimental studies of the results of college note-taking, Journal of Educational Research, 379-386. http://dx.doi.org/10.1080/00220671.1925.10879612

Di Vesta, F. J., \& Gray, G. S. (1973). Listening and note taking: II. Immediate and delayed recall as functions of variations in thematic continuity, note taking, and length of listening review intervals. Journal of Educational Psychology, 64(3), 278-287. http://dx.doi.org/10.1037/h0034589

Dunkel, P. \& S. Davy. (1989). The heuristic of lecture note-taking: perceptions of American and international students regarding the value and practice of note-taking. English for Specific Purposes Journal, 8(1), 33-50. http://dx.doi.org/10.1016/0889-4906(89)90005-7

Eggert, A. C., \& Williams, R. L (2002). Notetaking in College Classes: Student Patterns and Instructional Strategies. The Journal of General Education, 51(3), 173-199. http://dx.doi.org/10.1353/jge.2003.0006

Faber, J. E., Morris, J. D., \& Lieberman, M. G. (2000). The effect of note taking on ninth grade students' comprehension. Reading Psychology, 21, 257-270. http://dx.doi.org/10.1080/02702710050144377

Fisher, J. L., \& Harris, M. B. (1973). Effect of note-taking preference and type of notes taken on memory. Psychological Reports, 35, 384-386. http://dx.doi.org/10.2466/pr0.1974.35.1.384

Friend, R. (2001). Effects of strategy instruction on summary writing of college students. Contemporary Educational Psychology, 26, 3-24. http://dx.doi.org/10.1006/ceps.1999.1022

Graham, S., Berninger, V. M., Abbott, R. D., Abbott, S. P., \& Whitaker, D. (1997). Role of mechanics in composing of elementary school students: A new methodological approach. 
$\begin{array}{lllll}\text { Journal of } & \text { Educational } & \text { Psychology, } & 89, & \text { 170-182. }\end{array}$ http://dx.doi.org/10.1037/0022-0663.89.1.170

Gray, T., \&Madson, L. (2007). Ten easy ways to engage your students. College Teaching, 55(2), 83-87. http://dx.doi.org/10.3200/CTCH.55.2.83-87

Hartley, J. (1983). Notetaking Research: Resetting the scoreboard. Bulletin of the British Psychological Society, 36, 13-14.

Jonassen, D. H. (1984). Effects of generative text processing strategies on recall and retention. Human Learning, 3(4), 241-256.

Jones, D., \& Christensen, C. A. (1999). Relationship between automaticity in handwriting and students' ability to generate text. Journal of Educational Psychology, 91, 44-49. http://dx.doi.org/10.1037/0022-0663.91.1.44

Kiewra, K. A. (1984). Acquiring effective notetaking skills: An alternative to professional note-taking. Journal of Reading, 27,299-302.

Kiewra, K. A. (1985a). Learning from a lecture : An investigation of note-taking, review and attendance at a lecture. Human Learning, 4, 73-77.

Kiewra, K. A. (1985b). Students' note-taking behaviors and the efficacy of providing the instructor's note for review. Contemporary Educational Psychology, 10, 378- 386. http://dx.doi.org/10.1016/0361-476X(85)90034-7

Kiewra, K. A., Benton, S. L., Kim, S., Risch, N., \& Christensen. (1995). Effect of note-taking format and study technique on recall and relational performance. Contemporary Educational Psychology, 20, 172-187. http://dx.doi.org/10.1006/ceps.1995.1011

Lewis, M., \& Hill, J. (1995). Practical Techniques for Language Teaching, Commercial Colour Press, London.

Meyer, J., (2002). Notetaking training: A worthwhile proposal? Retrieved January 15, 2009 from the World Wide Web: www.unca.edu/ mcglinn/jaymeyerrev Paper.doc

Najar, R.L. (1997). The effects of note taking strategy instruction on comprehension in ESL texts. (Unpublished doctoral dissertation). Hawaii University

Oxford .L. R. (1990). Language learning strategies, Heinle and Heinle Publishers, United States of America.

Peck, K. L. \& Hannafin, M J. (1983). The effect of note-taking pertaining and the recording of notes on the retention of aural instruction. Journal of Educational Research, 77(2), 100-07. http://dx.doi.org/10.1080/00220671.1983.10885506

Peper, R. J., \& Mayer, R. E. (1978). Note taking as a generative activity. Journal of Educational Psychology, 70(4), 514-522. http://dx.doi.org/10.1037/0022-0663.70.4.514s

Piolat, A., Olive, T., \& Kellogg R. T. (2004). Cognitive effort of note taking. Applied Cognitive Psychology, 18, 1-22. 
Quintus, L., Borr, M., Duffield, S., Napoleon, L., \& Welch, A. (2012). The impact of the Cornell note-taking method on students' performance in a high school family and consumer sciences class. Journal of Family and Consumer Sciences Education, 30(1), 27-38.

Spires, H. A., \& Stone, P. D. (1989). The directed note taking activity: A self-questioning approach. Journal of Reading, 33(1), 36-39.

Stahl, N. A., King, J. R., \& Henk, W. A. (1991). Enhancing students' note taking through training and evaluation. Journal of Reading, 34(8), 614-622.

Vigner, Gerard (1991). Reduction of information and generalization: Cognitive aspects of summery writing. Pratiques, 72(10), 33-53.

Ward, N., \& H. Tatsukawa (2003). A Tool for taking cass notes. International Human-computer Studies, 59(6), 959-981. http://dx.doi.org/10.1016/j.ijhcs.2003.07.003

White, J. C. (1996). Note-taking strategies and traces of cognition in language learning. RELC Journal, 27(1), 89-102. http://dx.doi.org/10.1177/003368829602700105

Williams, G. T. D. (2004). Assessment of 8th grade students' attitudes and perceptions of Cornell's note-taking. Unpublished doctoral dissertation, Union University.

WU, Y., \& Tsai, T. (2010). Effects of note-taking instruction and note-taking languages on college EFL students' listening comprehension. New Horizons in Education, 58(1), 120-132.

Zorn D. (2007), Increasing achievement scores with the use of the cornell note taking style, Retrieved from: http://www.heritage.edu/library/mastersprojects/Zorn_Donald_2007.pdf 